\title{
Facies and paleogeography of the Tertiary of the Lower Rhine Basin - sedimentary versus climatic control
}

\author{
T. Utescher ${ }^{1,3}$, V. Mosbrugger ${ }^{2}$ \& A.R. Ashraf ${ }^{2}$ \\ 1 Geologisches Institut, Nussallee 8, 53115 Bonn, Germany \\ 2 Institut für Geologie und Paläontologie der Universität Tübingen, 72119 Tübingen, \\ Germany \\ ${ }^{3}$ Corresponding author:Torsten Utescher; e-mail: utescher@geo.uni-bonn.de
}

Manuscript received: December 2001; accepted: January 2002

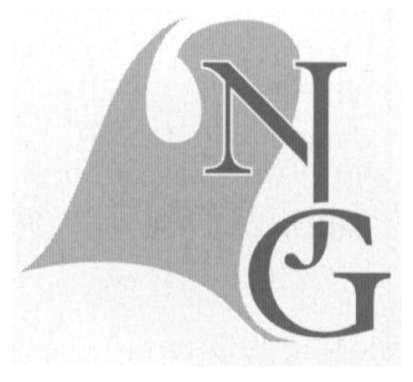

\begin{abstract}
Based on recent studies, the impact of global sea-level and climate change on the paleogeographic and sedimentary evolution of the Tertiary of the Lower Rhine Basin is analysed. It is shown that major changes in global climate and sea-level, such as the high-stand during the Middle Miocene climate optimum, the extreme low-stands near the base of the Tortonian and within the Messinian, are clearly reflected in the sedimentary succession. Continental climate curves, as reconstructed from Tertiary macrofloras of the Lower Rhine Basin, can be correlated with the marine, long-term isotope record. As shown by the analyses, a warm and humid climate with mean annual temperatures above $13^{\circ} \mathrm{C}$ and mean annual precipitation not below $1000 \mathrm{~mm}$, persisted throughout the Late Miocene to Early Pliocene. Continental, high-resolution, climate data show that Late Miocene alternations of lignites and clastics are rather caused by tectonic and sedimentary processes (such as the repeated migration of the river system) than by major climate changes.
\end{abstract}

Keywords: Lower Rhine Basin, paleoclimate, sedimentary facies, stratigraphy

\section{Introduction}

In the last ten years the paleogeographic evolution, paleovegetation and continental paleoclimate of the Tertiary of the Lower Rhine Basin have been intensely studied (e.g., Utescher et al., 1992; Hager, 1993; Schäfer et al., 1996; 1997; Van Adrichem Bogaert \& Kouwe, 1997). Additionally, the biostratigraphic resolution obtained for the continental part of the Tertiary strata has been refined (e.g., Ashraf \& Mosbrugger, 1995; 1996; Ashraf et al., 1997; Utescher et al., 2000; Schäfer et al., in press) and the regional paleoclimate has been studied in detail (Gebka et al., 1999; Utescher et al., 2000). Based on these results, the impact of global climate and sea level changes on the paleogeographic evolution of the Lower Rhine Basin in the Tertiary can be discussed, and the interdependencies of regional climate and sedimentary facies can be analysed.
The impact of global climate and sea level changes on the paleogeographic evolution of the Tertiary Lower Rhine Basin

In the Tertiary, the sedimentary record of the Lower Rhine Basin generally is characterised by continental deposits in the SE comprising fluviatile clastics with important browncoal seams, and open to shallow marine deposits in the NW (cf. facies section on Fig. 1). Numerous cycles of coastal onlap and offlap are present causing repeated shifts of the shoreline (cf. Teichmüller, 1974; Utescher et al., 1992).

In the Upper Oligocene section, marine sands alternate with continental clays and minor browncoal horizons (lower part of the Köln Formation). In the Late Chattian, a maximum transgression is reached with the deposition of the marine 'Sand 2' causing a marginal flooding of the surrounding Paleozoic base- 


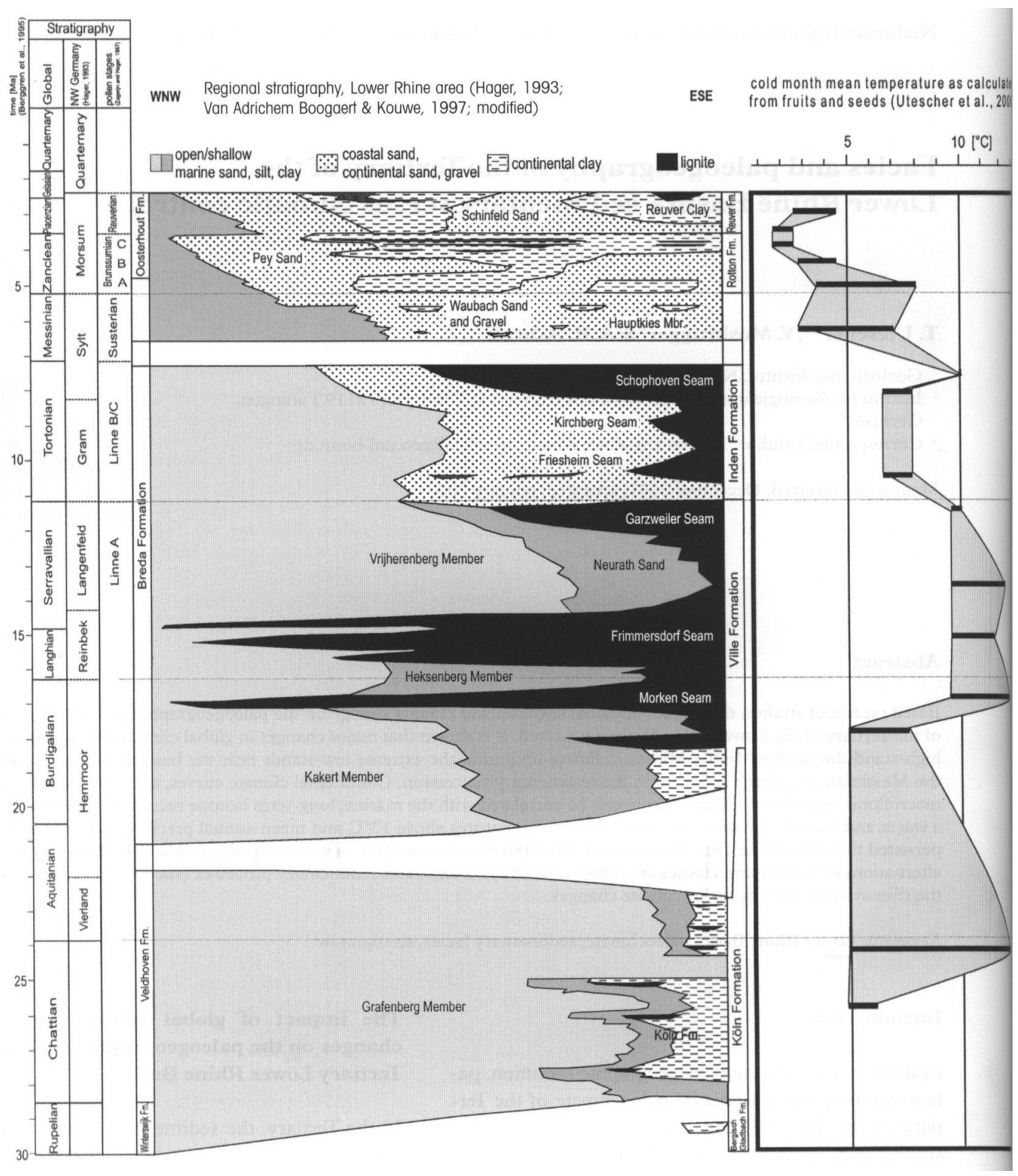

ment (Schäfer et al., 1997). This coastal onlap observed in the Lower Rhine Basin, most probably corresponds to a global sea level rise in the $\mathrm{Ch} 3$ chronostratigraphic sequence (cf. eustatic curves on Fig. 1; Hardenbol et al., 1998). Contemporaneously, the isotope-based paleotemperature curves indicate a global warming, which is well in accordance with the trend observed in the regional, terrestrial record (cf. cold month mean temperature record on Fig. 1).

In the later Early Miocene, the increase in temperature persisted, leading to the globally observed
Miocene warm interval which represents the warmest period in Neogene times. As evident from the continental climate record of the Lower Rhine Basin (Fig. 1), the major part of the Rhenish Main Seam (Morken I Seam, Frimmersdorf $a$ and $b$ Seams) and the lower part of the Neurath Sand can be correlated with this period. The Miocene warm interval corresponds to high global sea level stands from the Late Burdigalian to the Early Serravallian (chronostratigraphic sequences Bur 4 to Ser 1). In the sedimentary record of the Lower Rhine Basin, several 
10 $15\left[{ }^{\circ} \mathrm{C}\right]$ "modern", 4 $8\left[^{\circ} \mathrm{C}\right]$

$\begin{array}{cccc}2,5 & 2,0 & 1,5 & 1,0 \\ \perp & 1 & 1 & 1\end{array}$
Recalibrated to Gradstein et al. (1994), and Berggren et al. (1995) (Hardenbol et al., 1998)

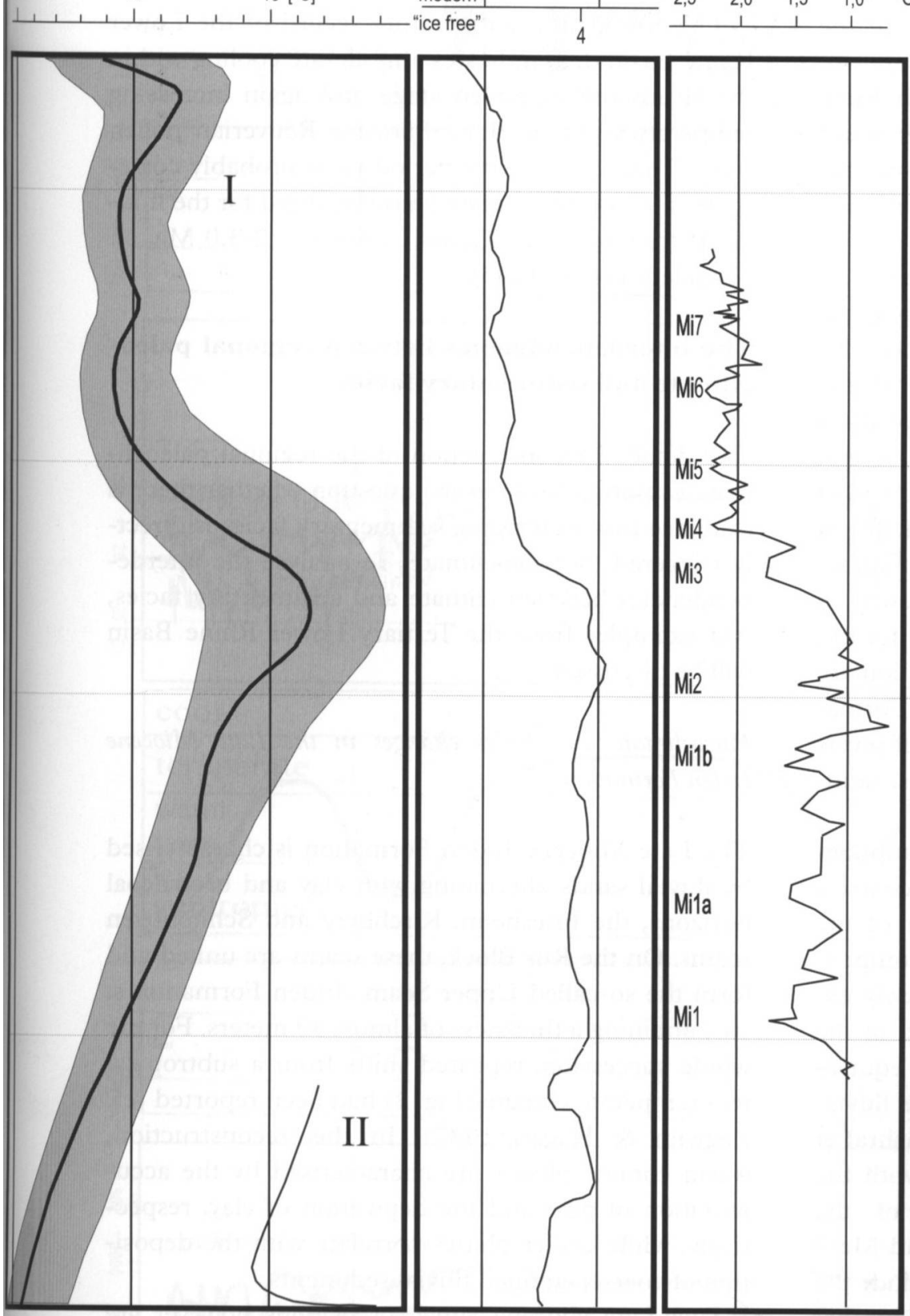

\begin{tabular}{cccc}
150 & 100 & 50 & $0 \mathrm{~m}$ \\
$\perp$ & $\perp$ & $\perp$ & $\perp$ \\
\hline
\end{tabular}

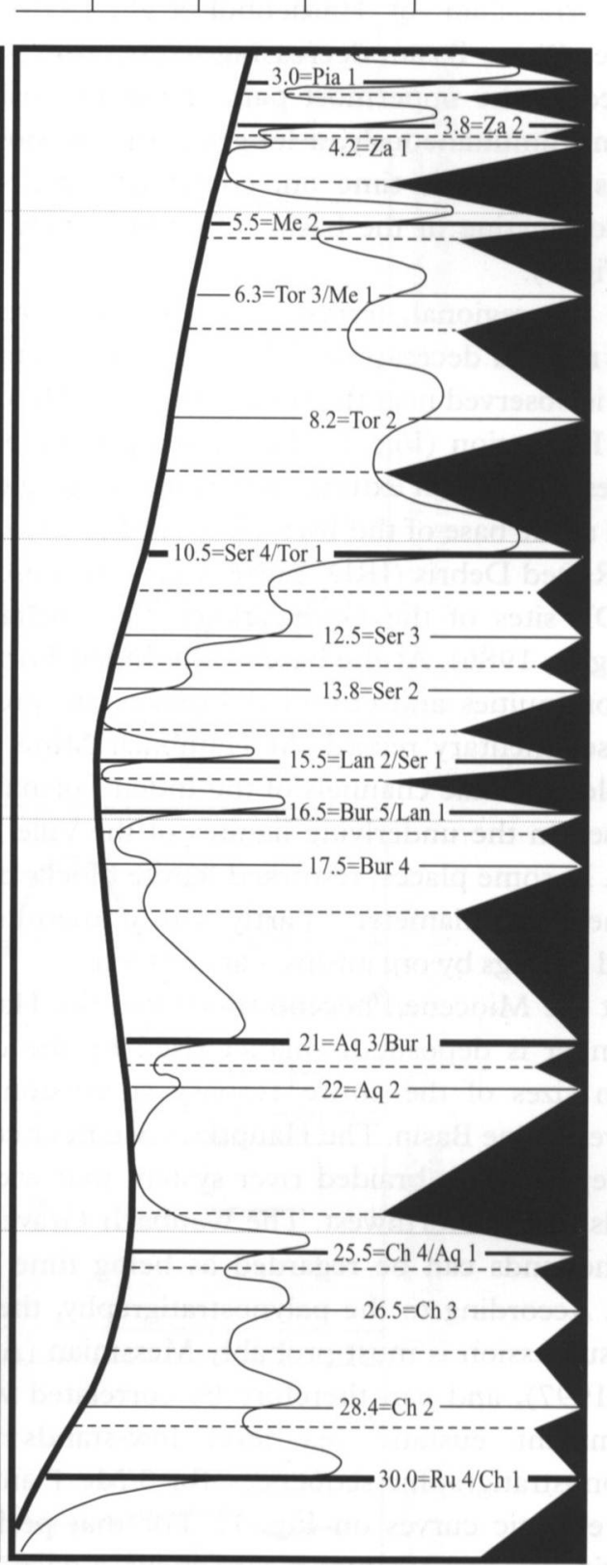

Fig. 1. Highly idealised facies section of the Lower Rhine Basin after Hager (1993) and Van Adrichem Bogaert \& Kouwe (1997) (modified), plotred with:

- the continental temperature record (cold month mean) as derived from fruit and seed floras by the coexistence approach (Mosbrugger $\&$ Utescher, 1997; Utescher et al., 2000),

- regional and global isotope records (SeaSurface Temperature (SST) of the Tertiary North Sea (Buchardt, 1978; Kohnen, 1995),

- SST (summary) of the Atlantic Ocean (Miller et al., 1987),

- SST of the E North Atlantic (Miller et al., 1991),

- eustatic curves with chronostratigraphic sequences (Hardenbol et al., 1998).

coastal offlaps are observed during that time, corresponding to the deposition of the Morken I and the Frimmersdorf $\mathrm{a}$ and $\mathrm{b}$ seams. Then, continental deposits can still be traced in the Roer Valley Graben in the Netherlands. The deposition of the overlying Neurath Sand, however, represents a phase of major coastal onlap. Marine sand forms a transgressive wedge on the Frimmersdorf peat, and the shore line is 
migrating southward, attaining the area of Hambach open cast mine on the Erft Block.

The globally observed Middle Miocene cooling at 14.1-14.8 $\mathrm{Ma}$ is correlated with an eustatic sea level fall and a regression facies cycle in the upper part of the Serravallian (cf. Hardenbol et al., 1998). In the Lower Rhine Basin, decreasing temperatures are observed in the uppermost part of the Rhenish Main Seam. Simultaneously, a long term regression trend starts. From this time on, continental deposits are predominating in the basin (cf. stratigraphic section on Fig. 1).

In the regional, terrestrial paleoclimate record, a very marked decrease in cold month means temperature is observed near the base of the Late Miocene Inden Formation (Fig. 1). This cooling most probably corresponds to an extreme low-stand of the global sea level at the base of the Tortonian. At that time, several Ice Rafted Debris (IRD) pulses were first observed in DSDP sites of the Greenlandian Sea (Schaeffer \& Spiegler, 1986). At the base of the Inden Formation, discontinuities and erosional surfaces are present in the sedimentary record. At Hambach Mine, for example, fluviatile channels of the Inden Formation are incised in the underlying lignites of the Ville Formation. In some places, reworked lignite blocks of several meters in diameter - partly with numerous, sandfilled borings by organisms - are observed.

At the Miocene/Pliocene transition, the Hauptkies Member is deposited, characterised by the coarsest grain sizes of the entire Tertiary succession of the Lower Rhine Basin. The Hauptkies Member comprises deposits of a braided river system that widely extends to the Northwest. The Waubach Gravel in the Netherlands can be regarded as being time equivalent. According to the palynostratigraphy, the fluviatile succession is most probably Messinian (Ashraf et al., 1997), and can therefore be correlated with the prominent eustatic sea level low-stands of the chronostratigraphic sequences Tor 3/Me 1 and $\mathrm{Me} 2$ (cf. eustatic curves on Fig. 1). For that period, the continental temperature record shows a decrease that can be referred to a glacial event within the Messinian at 6.2-6.3 Ma (cf. Shackleton et al., 1995).

In the Early Pliocene, increasing temperatures are observed in the isotope-derived temperature record of the Atlantic Ocean, and, correspondingly, in the continental temperature record of the Lower Rhine Basin for the Brunssumian A pollen stage (lower part of the Rotton Formation). This warm period at the base of the Pliocene can be correlated with a global sea level rise ( $\mathrm{Za} 1$ chronostratigraphic sequence). In the sedimentary record of the Lower Rhine Basin, the dominantly fine-grained sedimentation at that stratigraph- ic level might point to a comparatively high position of the erosional base. On the other hand, the coastal offlap persists and the shoreline is moving further to the NW, to Eindhoven in the Netherlands (Utescher et al., 1992).

The continental temperature record of the Lower Rhine Basin then indicates a moderate cooling within the Brunssumian pollen stage and again increasing temperatures in the Late Pliocene Reuverian pollen stage. This warmer time period most probably corresponds to a warm climate phase reported for the middle Piacenzian (early Gauss Chron at 3.2-3.0 Ma, cf. Shackleton et al., 1995).

\section{The interdependencies between regional paleo- climate and sedimentary facies}

The detailed reconstruction of the regional paleoclimate evolution leads to the question whether there is evidence that a changing sedimentary facies is directly triggered by paleoclimate. To analyse the interdependencies between climate and sedimentary facies, two examples from the Tertiary Lower Rhine Basin will be discussed.

\section{Paleoclimate and facies changes in the Late Miocene Inden Formation}

The Late Miocene Inden Formation is characterised by fluvial sands alternating with clay and browncoal horizons, the Friesheim, Kirchberg and Schophoven seams. On the Rur Block, these seams are united and form the so-called Upper Seam (Inden Formation s. str.) attaining a thickness of almost 30 meters. For the whole succession, repeated shifts from a subtropical to a temperate climate (Fig. 2) had been reported (cf. Zagwijn \& Hager, 1987). In this reconstruction, warm climate phases are characterised by the accumulation of peat and the deposition of clay, respectively, while cooler phases correlate with the deposition of coarser-grained fluvial sediments.

Such Late Miocene climate oscillations, however, are not observed in the temperature curves from Utescher et al. (2000) that have been calculated from megafloras and palynomorph sample sets using the coexistence approach (Fig. 2). All data presented herein indicate that the mean annual temperature (MAT) did not fall below $12.5^{\circ} \mathrm{C}$ during the deposition of the Inden Formation, with a mean annual precipitation (MAP) on a constantly high level of over $1000 \mathrm{~mm}$ (Utescher et al., $2000)$. However, slightly higher MATs $\left(-0.5-1^{\circ} \mathrm{C}\right)$ are calculated for the top of the Inden Formation corresponding to the 'Mastixia maximum' of von der Brelie (1968) and Zagwiin \& Hager (1987). 

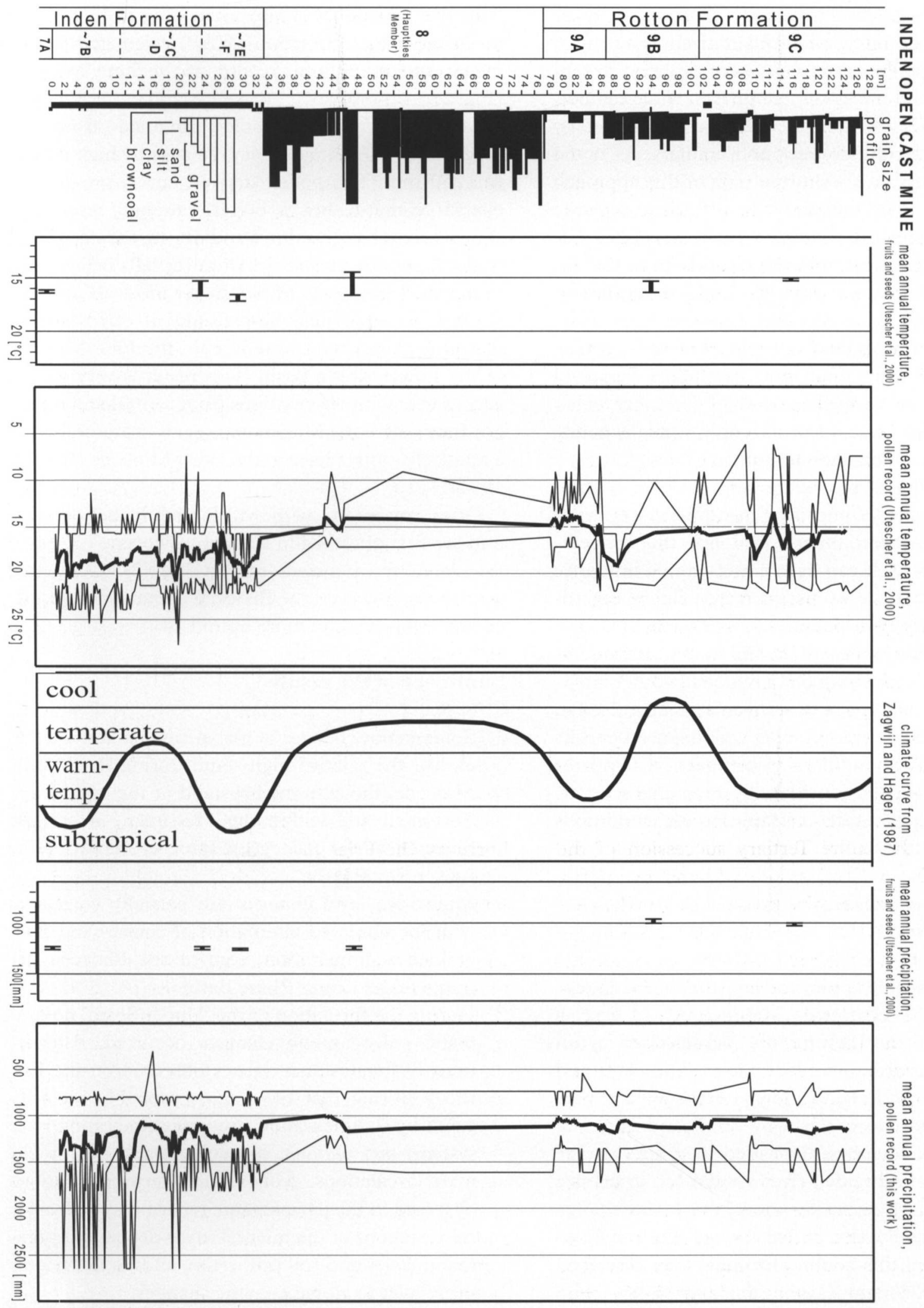

Fig. 2. Late Miocene to Early Pliocene succession at Inden open cast mine. Climate curves calculated from fruits and seeds and the palynological record by the coexistence approach (partly from Utescher et al., 2000). In the climate records calculated from the palynomorphs, the thin curves connect the lower and upper boundaries of coexistence intervals, the bold curve represents the gliding mean (periodicity $=3$ ).

The discrepancy between both climate reconstructions for the Inden Formation obviously is caused by the different approaches used in each case. Zagwijn \&
Hager (1987) extracted the upland elements from the palynospectra which were grouped with respect to their physiognomy, such as evergreen or broad-leaved 
deciduous trees. The frequency pattern of these groups was then interpreted qualitatively in terms of climate change. The evergreens were assumed to represent warm and moist climate phases, while temperate time periods were considered to be represented by broad-leafed-deciduous trees and conifers. As noted by these authors, it is a shortcoming of this approach that, in many cases, wherein it is difficult to separate the allochthonous from the autochthonous pollen, because most genera could have existed both in the upland vegetation as well as in the lowland vegetation. In addition, evergreen trees and shrubs are particularly common on peaty and nutrient-poor soils; hence, the facies signal may overprint the climate signal. In the paleoclimate reconstructions of Utescher et al. (2000) only the presence or absence of taxa is considered, thus excluding taphonomic bias.

As shown by a modelling approach in a Late Miocene time slice, comprising the uppermost part of the Inden Formation, there is evidence, that the sedimentary facies itself can have a measurable influence on local paleoclimate. Consequently, it can be regarded as a factor overprinting the climate signal in a similar way as the above described taphonomic effects. As evident from the analyses of 45 regionally differentiated microfloras with respect to mean annual and mean cold month temperature, areas with lignite deposits did show warmer conditions. A comparative temperature pattern has been generated by a regional scale atmospheric model under certain forcing conditions (Gebka et al., 1999).

Paleoclimate and sedimentary evolution at the Miocene / Pliocene transition

In the Lower Rhine Basin, the latest Miocene is represented by the Hauptkies Member. At its base, a major unconformity is present, characterised by an abrupt change in sedimentary facies. The clays and lignites of the underlying Inden Formation are partially re-eroded and overlain by sands and gravel of the Hauptkies Member, deposited in a high-energy environment of a braided river system (cf. grain size profile on Fig. 2). As stated above, this facies change can be correlated with a global cooling. For the Lower Rhine Basin, this cooling formerly was described by Menke (1975) and Zagwijn \& Hager (1987), who reconstructed a shift from a subtropical to a nearly cool climate (Fig. 2). According to Utescher et al. (2000), however, there is only evidence for a moderate cooling. With MAT between 13 and $16^{\circ} \mathrm{C}$ and CMM not below $3^{\circ} \mathrm{C}$, a warm temperate climate persisted in the Lower Rhine Basin during the latest Miocene.
In this context, it is also interesting to look at the mean annual precipitation (MAP) calculated for the mega- and microfloral record of the Late Miocene (Fig. 2).

According to the results obtained from the megafloras, MAP stays on a permanently high level of ca. $1250 \mathrm{~mm}$. The pollen derived curve, providing a coarser climatic, but a better temporal resolution, shows a minor decreasing trend during the deposition of the Upper Seam, but MAP never falls below 1000 $\mathrm{mm}$, when the means of parameter intervals are considered. Summarising these results, it can be stated that arid phases were absent from the Late Miocene of the Lower Rhine Basin. This result is very well in accordance with observations from central and northern Italy where the Messinian stage is characterised as a relatively moist phase in the latest Miocene (Bertini, 1994).

Drier conditions with MAT slightly below 1000 $\mathrm{mm}$ are first observed in the Early Pliocene (cf. MAP calculated from megafloras on Fig. 2). Compared with today, however, the Pliocene climate in the Lower Rhine Basin is still more humid.

\section{Summary of the results}

1. Some major changes in global climate and sea level, like the relative high-stand during the Middle Miocene, the extreme lowstand at the base of the Tortonian and within the Messinian, are clearly reflected in the paleogeographic evolution of the Lower Rhine Basin.

2. Minor sea level changes are partially correlated with the observed alternation of coarse- and finegrained sedimentation, e.g., in the Pliocene deposits of the Lower Rhine Basin.

3. During the formation of the 'Upper Seam' no dramatic paleoclimatic changes occurred. Alternations of lignites and clastics observed on the Erft Block during that time, most probably are triggered by sedimentation processes (migrating river system) and tectonic movements and not by climate oscillations. Minor short-term oscillations observed in the paleoclimate record may reflect local variations of the microclimate-dependant vegetation cover and soil properties, and do not necessarily refer to global climatic changes.

4. There is no evidence for dramatic changes, neither in temperature, nor in precipitation in the latest Miocene succession of the Lower Rhine Basin. Obviously, the abrupt facies change at the base of the Hauptkies Member is controlled by a sea level change and not by a changing climate. 


\section{Acknowledgements}

We thank Fritz Steininger (Frankfurt) and Hans Kerp (Münster) for carefully reading the manuscript.

\section{References}

Ashraf, A.R. \& Mosbrugger, V., 1995. Palynologie und Palynostratigraphie in der Niederrheinischen Bucht. Teil 1: Sporen. Palaeontographica, Abteilung B 235: 61-173.

Ashraf, A.R. \& Mosbrugger, V., 1996. Palynologie und Palynostratigraphie in der Niederrheinischen Bucht. Teil 2: Pollen. Palaeontographica, Abteilung B. 241: 1-98.

Ashraf, A.R., Mosbrugger, V. \& Utescher, T., 1997. Palynological studies in the Neogene of the open-pit mines Inden and Bergheim (Lower Rhine Embayment, Germany). Courier Forschungs-Institut Senckenberg 201: 29-46.

Bertini, A., 1994. Palynological investigation on Upper Neogene and Lower Pleistocene sections in Central and Northern Italy. Memorie de la Società Geologica Italiana 48: 431-443.

Buchardt, B., 1978. Oxygen isotope palaeotemperatures from the Tertiary period in the North Sea area. Nature 275: 121-123.

Gebka, M., Mosbrugger, V., Schilling, H.-D. \& Utescher, T., 1999. Regional scale palaeoclimate modelling on soft proxy-data basis - an example from the Upper Miocene of the Lower Rhine Embayment. Palaeogeography, Palaeoclimatology, Palaeoecology 152: 225-258.

Hager, H., 1993. The origin of the Tertiary lignite deposits in the Lower Rhine region, Germany. International Journal of Coal Geology 23: 251-262.

Hardenbol, J., Thierry, J., Farley, M.B., Thierry, J., de Graciansky, P.-C. \& Vail, P.R., 1998. Mesozoic and Cenozoic sequence chronostratigraphic framework of European basins. In: Graciansky, P.-C., Hardenbol, J., Thierry, J. \& Vail, P.R. (eds): Mesozoic and Cenozoic sequence stratigraphy of European basins. SEPM Special Publications 60: 3-14.

Kohnen, O., 1995. Palaeotemperatures from the Upper Oligocene of the North German Basin. Neues Jahrbuch der Geologie und Paläontologie, Abhandlungen 198: 233-241.

Menke, B., 1975. Vegetationsgeschichte und Florenstratigraphie Nordwestdeutschlands im Pliozän und Frühquartär, mit einem Beitrag zur Biostratigraphie des Weichselfrühglazials. Geologisches Jahrbuch A 26: 3-151.

Miller, K.G., Fairbanks, R.G. and Montain, G.S., 1987. Tertiary oxygen isotope synthesis, sea level history and continental margin erosion. Paleoceanography 2: 1-19.

Miller, K.G., Wright, J.D. \& Fairbanks, R.G., 1991. Unlocking the ice house: Oligocene-Miocene oxygen isotopes, eustasy and margin erosion. Journal of Geophysical Research 96: 6829-6848.

Mörs, T., Schäfer, A. \& Utescher, T., in press. Stratigraphy of the Cenozoic Lower Rhine Basin, north-western Germany. Newsletters on Stratigraphy.

Mosbrugger, V. \& Utescher, T., 1997. The coexistence approach - a method for quantitative reconstructions of Tertiary terrestrial palaeoclimate data using plant fossils. Palaeogeography, Palaeoclimatology, Palaeoecology 134: 61-86.

Schäfer, A., Hilger, D., Gross, G. \& von der Hocht, F., 1996. Cyclic sedimentation in Tertiary Lower Rhine Basin (Germany) the 'Liegendrücken' of the brown coal open cast Fortuna mine. Sedimentary Geology 103: 229-247.

Schäfer, A., Utescher, T. \& von der Hocht, F., 1997. Klastische Sedimentsysteme im Tertiär der Niederrheinischen Bucht. Terra Nostra 97/3: 68-113.

Schaeffer, R. \& Spiegler, D., 1986. Neogene cooling events and glacial phases in the North Atlantic. Zeitschrift der deutschen geologischen Gesellschaft 137: 537-552.

Shackleton, N.J., Hall, M.A. \& Pate, D., 1995. Pliocene stable isotope stratigraphy of Site 846 . Proceedings ODP, Scientific Results 138: 337-353.

Teichmüller, M., 1974. Die Tektonische Entwicklung der Niederrheinischen Bucht. In: Illies, J.H. \& Fuchs, K. (eds): Approaches to taphrogenesis. Schweizerbart (Stuttgart): 269-285.

Utescher, T., Ashraf, A.R. \& Mosbrugger, V., 1992. Zur Faziesentwicklung im Neogen der Niederrheinischen Bucht. In: KovarEder, J. (ed.): Palaeovégetational development in Europe. (Wien): $235-243$.

Utescher, T., Mosbrugger, V. \& Ashraf, A.R., 2000. Terrestrial climate evolution in Northwest Germany over the last 25 million years. Palaios 15: 430-449.

von der Brelie, G., 1968. Zur mikrofloristischen Schichtengliederung im rheinischen Braunkohlenrevier. Fortschritte in der Geologie von Rheinland und Westfalen 16: 85-102.

Van Adrichem Boogaert, H.A.\& Kouwe, W.F.P, 1997. Stratigraphic nomenclature of the Netherlands, revision and update by RGD and NOGEPA. Mededelingen Rijks Geologische Dienst 50: 1-37.

Zagwijn, W. \& Hager, H., 1987. Correlation of continental and marine Neogene deposits in the Southeastern Netherlands and the Lower Rhine district. Mededelingen van de Werkgroep voor Tertiaire en Kwartair Geologie 24 (1-2): 59-78. 